\title{
Nutritional and energy values of sunflower cake for broilers
}

\section{Valores nutricionais e energéticos da torta de girassol para frangos de corte}

\author{
Eveline Berwanger ${ }^{*}$; Ricardo Vianna Nunes ${ }^{2}$; Paulo César Pozza \\ Taciana Maria Moraes de Oliveira ${ }^{4}$; Carina Scherer ${ }^{5}$; Rafael Frank ${ }^{6}$; \\ Douglas Fernando Bayerle ${ }^{6}$; Jeffersson Rafael Henz ${ }^{7}$
}

\begin{abstract}
The study aimed to determine the nutritional and energy values of sunflower cake for broilers through two experiments. The first study evaluated the energy values by the method of total excreta collection, using 100 broiler chicks $21-31$ days old, divided into five treatments of $0 \%, 10 \%, 20 \%, 30 \%$ and $40 \%$ inclusion sunflower cake will reference a diet. The second experiment evaluated the influence of the period and the quantity supplied of sunflower cake on digestibility of amino acids by a forcedfeeding technique. Eighteen cockerels were used, divided into three treatments, which consisted of supplying $15 \mathrm{~g}$ of sunflower cake, $30 \mathrm{~g}$ of sunflower cake (15 g at intervals of 12 hours) and $30 \mathrm{~g}$ of sunflower cake ( $15 \mathrm{~g}$ at intervals of 24 hours), and an additional six roosters were fasted for correction of metabolic and endogenous losses. The samples were sent for amino acid analysis by HPLC in the Evonik Laboratory (Germany), and chemical and energy analysis to Unioeste Laboratory. The values of apparent metabolizable energy (AME), metabolization coefficient (AMC), apparent metabolizable energy corrected for nitrogen balance (AMEn), metabolization coefficient corrected for nitrogen balance (AMCn) for sunflower cake were $2211.68 \mathrm{kcal} . \mathrm{kg}^{-1}, 2150.54 \mathrm{kcal}^{\mathrm{kg}}{ }^{-1}, 45.47 \%$ and $44.73 \%$, respectively. The amount of food provided in the feeding method changed the assessment of true digestibility of amino acids (TDCA), and when only $15 \mathrm{~g}$ was used, the values of true digestibility coefficients were underestimated. The lysine, histidine and threonine amino acids were at lower TDCA, and arginine and methionine showed the highest TDCA for sunflower cake.
\end{abstract}

Key words: Birds, digestibility, metabolism, nutrition

\section{Resumo}

O trabalho teve como objetivo determinar a composição nutricional e os valores energéticos da torta de girassol para frangos de corte através de 2 experimentos. No primeiro avaliou-se os valores energéticos através do método de coleta total de excretas, utilizando 100 frangos de corte de 21 a 31 dias de idade, distribuídos em 5 tratamentos de 0, 10, 20, 30 e 40\% de

\footnotetext{
${ }^{1}$ M.e em Zootecnia, Universidade Estadual do Oeste do Paraná, UNIOESTE, Marechal Cândido Rondon, PR, Brasil. E-mail: evelineberwanger@hotmail.com

2 Prof., Centro de Ciências Agrárias, UNIOESTE, Marechal Cândido Rondon, PR, Brasil. E-mail: nunesrv@hotmail.com

3 Prof., Universidade Estadual de Maringá, UEM, Maringá, PR, Brasil. E-mail: pcpozza@yahoo.com.br

${ }^{4}$ Discente de Doutorado em Zootecnia, UEM, Maringá, PR, Brasil. E-mail: tacideoliveira@hotmail.com

${ }^{5}$ Dra. em Zootecnia, UNIOESTE, Marechal Cândido Rondon, PR. E-mail: carina_scherer@hotmail.com

${ }^{6}$ Discentes de Mestrado em Zootecnia, UNIOESTE, Marechal Cândido Rondon, PR, Brasil. E-mail: douglas_fernandob@hotmail. com; rafaelfrankrafael@hotmail.com

7 M.e em Zootecnia, UNIOESTE, Marechal Cândido Rondon, PR, Brasil. E-mail: jeffersson_henz@hotmail.com

* Author for corespondence
} 
inclusão da torta de girassol á uma dieta referência. No segundo experimento foi avaliada a influência do período e da quantidade fornecida da torta de girassol sobre a digestibilidade dos aminoácidos, através da técnica de alimentação forçada. Foram utilizados 24 galos cecectomizados, distribuídos em 3 tratamentos, os quais consistiram no fornecimento de apenas $15 \mathrm{~g}$ de torta de girassol, de $30 \mathrm{~g}$ de torta de girassol (15 g com intervalo de $12 \mathrm{~h}$ ), e de $30 \mathrm{~g}$ de torta de girassol ( $15 \mathrm{~g}$ com intervalo de $24 \mathrm{~h}$ ) e simultaneamente 6 galos foram mantidos em jejum para correção das perdas endógenas e metabólicas. As amostras foram enviadas para análise de aminoácidos pelo HPLC no Laboratório da Evonik (Alemanha), e bromatológica e de energia ao Laboratório da Unioeste. Os valores de energia metabolizável aparente (AME), coeficiente de metabolizabilidade (CME), energia metabolizável aparente corrigida pelo balanço de nitrogênio $\left(\mathrm{AME}_{\mathrm{n}}\right.$ ), coeficiente de metabolizabilidade corrigido pelo balanço de nitrogênio $\left(\mathrm{CME}_{\mathrm{n}}\right)$ para a torta de girassol foram de 2.211,68 kcal.kg-1, 2.150,54 kcal. $\mathrm{kg}^{-1}, 45,47 \%$ e $44,73 \%$, respectivamente. A quantidade de alimento fornecido no método de alimentação forçada alterou a avaliação do coeficiente de digestibilidade verdadeira dos aminoácidos (CDVA), sendo que quando utilizado apenas $15 \mathrm{~g}$, os valores de coeficiente de digestibilidade verdadeiro foram subestimados. A lisina, histidina e treonina foram os aminoácidos com menores CDVA, e a arginina e a metionina apresentaram os maiores CDVA para a torta de girassol.

Palavras-chave: Aves, digestibilidade, metabolismo, nutrição

\section{Introduction}

Corn and soybean meal are the main ingredients of feed for broilers, and their supply is associated with the highest cost in poultry production (COSTA; SILVA; PINHEIRO, 2005). In an attempt to reduce production costs, many products have been evaluated in anticipation of partial substitution of corn and soybean meal.

Among the alternative foods recently evaluated, the by-products of biofuel industries have attracted much attention. In particular, the sunflower crop represents one of the most important agricultural bases of the national program of fuels from renewable sources (PEDREIRO et al., 2009). In recent years, the cultivation of sunflower has expanded significantly, especially in the midwest region of Brazil (SILVA; AGOSTINI, 2007). In $2011 / 2012$, the crop area planted with sunflower in Brazil was estimated at 74,500 hectares and harvested 116,800 tons of grain (CONAB, 2012).

The sunflower is among the five largest oilseed crops that produce edible vegetable oil in the world, behind only soybeans, canola, cotton and peanuts (OLIVEIRA; VIEIRA, 2004). The extraction process of sunflower oil is carried out by two methods. The first and most efficient process uses chemical solvent (hexane), associated with a high temperature, which is obtained as a by-product of sunflower meal. The second method is characterized by cold pressing of sunflower seeds by means of mechanical presses to obtain the crude oil, resulting in a dough that is characterized as a sunflower cake by-product, which has a higher content of fat meal compared to sunflower, due to lower efficiency of oil extraction from the seed (OLIVEIRA et al., 2012).

The sunflower cake has protein and energy that can supply part of the nutrient requirements in animal feed (SANTOS et al., 2009). However, according to Pereira et al. (2011), the variability in nutrient content is higher for the co-products than for conventional foods, so frequent analysis of its chemical composition and nutritional and productive parameters should be performed. The variations are due to genetic variety and the type and setting of press used in the processing of grains (OLIVEIRA et al., 2007) directly affecting its nutritional quality.

The inclusion of sunflower cake in the diets of 
broiler chickens is dependent mainly bromatological composition and its nutritional composition and energy value (OLIVEIRA et al., 2012), and so the knowledge of these parameters is important. It is extremely important to know the values of digestible amino acids, since the use of these formulations can reduce excess losses of these components in the diet, although these data are scarce. Besides the knowledge of the values of digestible amino acids, the precise knowledge of the metabolizable energy values of foods used in feed formulation to obtain a diet that meets the nutritional requirements of broilers is necessary (PELIZZERI et al., 2013).

The objective of this study was to evaluate the digestibility of amino acids and to obtain the values of metabolizable energy of sunflower cake for broiler chickens.

\section{Materials and Methods}

Two experiments were conducted at the Experimental Farm Professor Antonio Carlos dos Santos Pessoa of Universidade Estadual do Oeste do Paraná, Campus of Marechal Candido Rondon (PR, Brazil). The first experiment evaluated the energy values and coefficients of metabolizable energy of the sunflower cake in diets for broilers, and the second experiment assessed the value of digestible amino acids and obtained the true digestibility coefficients of amino acids.

The work was performed at the Laboratory of Physiology and Metabolism Poultry Unioeste. The sunflower cake used in this work was obtained after oil extraction by cold pressing of whole sunflower seed production in the oil industry, located in the region of Toledo (PR, Brazil).

Samples of sunflower cake were sent to the laboratory of Animal Nutrition Unioeste to determine the dry matter (DM), crude protein (CP), ether extract (EE), neutral detergent fibre (NDF), acid detergent fibre (ADF), gross energy (GE), mineral matter (MM), calcium and phosphorus according to techniques described by Silva and Queiroz (2002).
In the first experiment to determine the energy value, total collection of excreta broiler (21-31 days of age) was used. One hundred broilers at 21 days of age with an average weight of $915+9.45 \mathrm{~g}$, distributed in four treatments, and a reference diet with four replicates, and an experimental unit of five animals each. The sunflower cake replaced $(\mathrm{kg}$. $\mathrm{kg}^{-1}$ ) $10 \%, 20 \%, 30 \%$ and $40 \%$ of the reference diet (Table 1), which was formulated according to the requirements proposed by Rostagno et al. (2011) for broilers 21-31 days old.

The trial period for the determination of metabolizable energy lasted 10 days, 5 days for adaptation and 5 for total excreta collection. The excreta of all experimental units (EU) were collected at intervals of 12 hours in trays covered with plastic to prevent fermentation. The collected material was placed in plastic bags and stored in a freezer until the end of the collection period.

At the end of the collection period, were determined on feed intake and the total amount of excreta produced by EU and subsequently thawed, homogenized and a sample of known weight of each withdrawal repetition and dry in oven with forced ventilation at $55^{\circ} \mathrm{C}$ for 72 hours to determine the dry sample in air (ASA). After pre-drying, the samples were ground in a knife mill, and analyses of dry matter, gross energy and nitrogen were performed.

Based on the analysis results, the values of apparent metabolizable energy (AME) and apparent metabolizable energy corrected for nitrogen balance (AMEn) were calculated using the equations proposed by Matterson, Potter and Stutz (1965). After determination of metabolizable energy, coefficients of metabolizable energy (CME and CMEn) were calculated.

The second experiment was conducted to determine the digestible amino acids of sunflower cake. One bioassay was performed using the technique of force-feeding (SIBBALD, 1976) with cecectomized adult cockerels with an average weight of $1912.10 \pm 133.73 \mathrm{~g}$. The experimental design was 
completely randomized and was composed of three treatments with different times between supply and different quantities of the test food (sunflower cake) to evaluate possible influences of the methodology employed in the true digestibility of the food.

Table 1. Percentage and chemistry composition of the reference diet.

\begin{tabular}{|c|c|}
\hline Ingredients & $\begin{array}{c}\text { Quantity } \\
(\%)\end{array}$ \\
\hline Corn grain & 57.68 \\
\hline Soybean meal & 34.53 \\
\hline Soybean oil & 4.50 \\
\hline Dicalcium phosphate & 1,10 \\
\hline Limestone & 1.01 \\
\hline Common salt & 0.46 \\
\hline DL-Methionine (99\%) & 0.27 \\
\hline L-Lysine.HCl (78\%) & 0.17 \\
\hline L-Threonine (98\%) & 0.03 \\
\hline Vitamins $^{1}$ & 0.10 \\
\hline Minerals $^{2}$ & 0.05 \\
\hline Choline chloride $(60 \%)$ & 0.06 \\
\hline Antioxidant $^{3}$ & 0.02 \\
\hline Total & 100.00 \\
\hline \multicolumn{2}{|l|}{ Nutrients } \\
\hline Digestible Arginine (g.kg-1) & 12.9 \\
\hline Digestible Isoleucine $\left(\mathrm{g} \cdot \mathrm{kg}^{-1}\right)$ & 8.8 \\
\hline Digestible Leucine (g. $\left.\mathrm{kg}^{-1}\right)$ & 16.2 \\
\hline Digestible Lysine $\left(\mathrm{g} \cdot \mathrm{kg}^{-1}\right)$ & 11.3 \\
\hline Digestible Methionine + Cysteine $\left(\mathrm{g} \cdot \mathrm{kg}^{-1}\right)$ & 8.2 \\
\hline Digestible Methionine (g. $\left.\mathrm{kg}^{-1}\right)$ & 5.4 \\
\hline Digestible Threonine $\left(\mathrm{g} \cdot \mathrm{kg}^{-1}\right)$ & 7.3 \\
\hline Digestible Tryptophan $\left(\mathrm{g} / \mathrm{kg}^{-1}\right)$ & 2.2 \\
\hline Digestible Valine $\left(\mathrm{g}^{\mathrm{kg}} \mathrm{kg}^{-1}\right)$ & 8.7 \\
\hline Metabolizable energy $\left(\mathrm{kcal} \mathrm{kg}^{-1}\right)$ & 3150 \\
\hline Protein $\left(\mathrm{g} \cdot \mathrm{kg}^{-1}\right)$ & 205.0 \\
\hline Potassium $\left(\mathrm{g} \cdot \mathrm{kg}^{-1}\right)$ & 7.9 \\
\hline Sodium $\left(\mathrm{g} \cdot \mathrm{kg}^{-1}\right)$ & 2.0 \\
\hline Calcium (g.kg-1) & 7.5 \\
\hline Available phosphorus (g. $\left.\mathrm{kg}^{-1}\right)$ & 3.2 \\
\hline
\end{tabular}

${ }^{1}$ Vitamin supplement, content: Vit. A - 10,000,000 UI; Vit. D3 2,000,000 UI; Vit. E - 30,000 UI; Vit. B1 - 2.0 g; Vit. B6 - 4.0 g; Pantothenic Ac. -12.0 g; Biotin -0.10 g; Vit. K3 - 3.0 g; Folic Acid - 1.0 g; Nitocinic Ac. - 50.0 g; Vit. B12 - 15,000 mcg; Selenium - $0.25 \mathrm{~g}$; and Vehicle q.s.p. $-1,000 \mathrm{~g}$; ${ }^{3} \mathrm{Mineral}$ supplement, content: $\mathrm{Mg}-16.0 \mathrm{~g} ; \mathrm{Fe}-100.0 \mathrm{~g} ; \mathrm{Zn}-100.0 \mathrm{~g}$; $\mathrm{Cu}-2.0 \mathrm{~g} ; \mathrm{Co}-2.0 \mathrm{~g} ; \mathrm{I}-2.0 \mathrm{~g}$ and Vehicle q.s.p. $-1,000 \mathrm{~g}$; ${ }^{3}$ BHT (hydroxybutyl toluene).

Source: Elaboration of the authors.
The first treatment consisted of providing $15 \mathrm{~g}$ of sunflower cake. The second treatment consisted of providing $30 \mathrm{~g}$ of food divided into two supply periods (15 g with an interval of 12 hours), which was recommended by Sibbald (1976) for foods that may cause regurgitation. The third treatment consisted of providing $30 \mathrm{~g}$ divided into two periods (15 g every 24 hours). Each treatment consisted of six replicates and one rooster per experimental unit.

Before the start of the collection period, the roosters were housed in individual cages and metal batteries during an adjustment period of 5 days, were fed 2 hours a day divided into two shifts, 8:00 and 16:00 hours, aiming dilatation of the crop.

After the adjustment period, during the first 24 hours, the roosters were fasted in order to empty the digestive tract, and then the birds were forced to eat the test food through a funnel-tube, inserted through the oesophagus into the crop. In parallel, six cockerels housed under the same conditions were fasted, totalling 24 roosters.

The total collection was started after the first 12 hours after delivery of food, and continued every 12 hours to prevent fermentation, for a period of 56 hours after the last delivery. The excreta were quantified and put in a freezer. At the end of the collection period, the samples were thawed, homogenized and dried by forced ventilation at $55^{\circ} \mathrm{C}$ for 72 hours and ground in a knife mill. The samples were divided into three treatments by pooling.

The values obtained for birds fasting were used to make the corresponding corrections to the metabolic and endogenous losses of amino acids. The aminograms of food and excreta were performed by high-performance liquid chromatography (HPLC) in the Laboratory of EVONIK LTDA, located in Germany.

Obtaining values of intake and excrete amino acids, and knowing the endogenous fraction obtained cockerels fasted, we determined the true digestibility coefficients of each amino acid in foods 
of different treatments using the formula described by Rostagno and Featherston (1977).

The results from the two experiments were subjected to analysis of variance, and subsequently, the results for the energy values were subjected polynomial regression for the inclusion levels of sunflower cake (10-40\%), and the true digestibility coefficients of amino acids was determined using the SNK 5\% probability test.

\section{Results and Discussion}

In the nutritional composition obtained from sunflower after cake high content of ether extract, neutral detergent fibre and acid detergent fibre (Table 2) can be observed. According to Pedreiro et al. (2009), sunflower cake containing a higher concentration of bran oil, as results from the grain crushing process and can, according to Aguiar et al. (2001), if not stripped before crushing, have high fibre content.

Table 2. Bromatological composition and gross energy value in the natural matter of sunflower cake.

\begin{tabular}{lc}
\hline Composition & Sunflower cake \\
\hline Dry matter (\%) & 92.17 \\
Crude protein (\%) & 24.37 \\
Gross energy (kcal.kg-1) & 4819 \\
Ether extract (\%) & 23.80 \\
Neutral detergent fibre (\%) & 35.32 \\
Acid detergent fibre (\%) & 22.30 \\
Mineral matter (\%) & 4.10 \\
Calcium (\%) & 0.725 \\
Total phosphorus (\%) & 0.228 \\
\hline
\end{tabular}

Source: Elaboration of the authors.

Chung et al. (2009) evaluated the composition of sunflower cake, and found, in natural materials, moisture $8.29 \%$ and $4.45 \%$ mineral material; these levels similar to those achieved since the values of crude protein, NDF and ADF found by Chung et al. were $27.79 \%, 39.63 \%$ and $37.49 \%$, respectively, which is higher than those obtained in this work. However, the ether extract was lower (19.90\%). The results obtained by Silva et al. (2003) were $7.57 \%$ moisture, $22.19 \%$ crude protein, $22.15 \%$ ether extract and $4.68 \%$ mineral material, showing greater similarity in nutritional content.

The values found in the literature indicate great variability in the results for the nutritional components of sunflower cake. The genetic variety of the plant, the soil type, climate and cultural practices, as well as the methods of extraction and processing of oil, are cited as reasons for the wide compositional range (KARUNAJEEWA; THAN; ABU-SEREWA, 1989; VIEIRA et al., 1992).

Levels did not affect $(\mathrm{P}>0.05)$ the apparent metabolizable energy and the coefficient of apparent metabolizable energy (Table 3). However, the values of apparent metabolizable energy corrected for nitrogen balance and its respective metabolization coefficient were influenced ( $P$ $<0.05$ ) by the inclusion of sunflower cake in the reference diet, according to the equation AMEn $=2275.40-4.99430 \mathrm{X}\left(\mathrm{R}^{2}=0.59\right)$ and CMEn = $47.2173-0.103638 X\left(\mathrm{R}^{2}=0.59\right)$. These results are based on the fact that in growing birds, the protein retained in the body of the bird, and consequently not catabolized by the products of excretion of nitrogen, does not contribute to the energy of faeces and urine. Thus, the correction for nitrogen balance increased the difference between treatments, unlike the apparent metabolizable energy and its metabolizable coefficient that takes into account this retention (SAKOMURA; ROSTAGNO, 2007).

The AMEn and CMEn decreased with increasing sunflower cake in the diet. These results may be related to the high content of fibre in the diet, which causes a substantial drop of metabolizable energy for poultry. 
Table 3. Values of AME, AMEn, CME and CMEn in response to the different levels of inclusion of sunflower cake.

\begin{tabular}{ccccc}
\hline Levels & AME $\left(\mathrm{kcal}_{\mathrm{kg}} \mathrm{k}^{-1}\right)$ & AMEn $\left(\mathrm{kcal}^{\mathrm{kg}}{ }^{-1}\right)$ & CME $(\%)$ & CMEn (\%) \\
\hline 10 & 2280 & 2276 & 47.31 & 47.23 \\
20 & 2191 & 2108 & 45.47 & 43.73 \\
30 & 2186 & 2109 & 45.36 & 44.21 \\
40 & 2189 & 2109 & 43.77 & 43.76 \\
\hline $\mathrm{CV}$ & 3.662 & 3.656 & 3.622 & 3.656 \\
\hline $\mathrm{P}^{1}$ & 0.188 & 0.036 & 0.188 & 0.036 \\
\hline Linear & 0.1523 & 0.0148 & 0.1523 & 0.0148 \\
Quadratic & 0.2789 & 0.0583 & 0.2789 & 0.0583 \\
Cubic & 0.6935 & 0.3482 & 0.6935 & 0.3482 \\
\hline
\end{tabular}

${ }^{1} \mathrm{P}<0.05$ : Significant effect.

Source: Elaboration of the authors.

The digestion and utilization of nutrients are affected by the physical and chemical properties of dietary fibre (WENK, 2001). The main nonstarch polysaccharides found in plants are cellulose, pectin, $\beta$-glucans, pentosans and xylans, and they cannot be hydrolysed by endogenous enzymes for non-ruminant animals (MONTAGNE; PLUSKE, HAMPSON, 2003). When divided on its solubility considered soluble fibre (pectin, gums, $\beta$-glucans, mucilages and some hemicelluloses) generally acts as an active component in the regulation of digestion and intestinal absorption, and insoluble dietary fibre increases the cake food, diluting the nutrients and decreasing gastrointestinal transit time (CUMMING, EDMOND; MAGEE, 2004).

According to Freitas et al. (2006), the presence of soluble fibre in the sunflower bran may increase intestinal viscosity, hindering the digestion and absorption of nutrients, mainly lipids, which results in lower utilization of energy. Ramos et al. (2007) state that the soluble fibre in contact with water forms a gel that acts as a barrier to the action of hydrolytic enzymes, because it hinders the contact of these with the starch granules and the protein and lipid molecules, thus decreasing the contact of the bolus with the absorptive cells of the intestinal membrane. This causes a reduction in digestion and absorption of nutrients from the feed occurs.

Other factors that can directly influence the amount of metabolizable energy are the amount of mineral matter and the type of fat present in the food (GENEROUS et al., 2008).

The average AMEn was $2150 \mathrm{kcal}_{\mathrm{kg}}{ }^{-1}$, which is lower than the results found in the literature. Pinheiro et al. (2007), Oliveira et al. (2012) and Fonseca et al. (2007) observed in digestibility trials AMEn values of $3115 \mathrm{kcal} . \mathrm{kg}^{-1}, 2800$ and 2928 kcal. $\mathrm{kg}^{-1}$, respectively.

The use of only $15 \mathrm{~g}$ of food underestimated the results, with values of coefficients of the true digestibility of amino acids lower than when using $30 \mathrm{~g}$, which was probably due to the minor amount of supplied food (Table 4). 
Table 4. Coefficients of true digestibility of amino acids, the total amino acids (TAA) and digestible amino acids (DAA) of sunflower cake.

\begin{tabular}{|c|c|c|c|c|c|c|}
\hline & \multicolumn{3}{|c|}{ True digestibility coefficient } & \multirow[t]{2}{*}{$\mathrm{CV}^{1}$} & \multirow[t]{2}{*}{$\mathrm{AAt}^{2}$} & \multirow[t]{2}{*}{$\mathrm{AAd}^{3}$} \\
\hline & $30 \mathrm{~g} / 12 \mathrm{~h}$ & $30 \mathrm{~g} / 24 \mathrm{~h}$ & $15 \mathrm{~g}$ & & & \\
\hline \multicolumn{7}{|c|}{ Essential amino acids } \\
\hline Lysine & $70.77_{\mathrm{a}}$ & $73.55_{a}$ & $57.07_{b}$ & 15.35 & 0.85 & 0.60 \\
\hline Threonine & 60.59 & 66.18 & 49.00 & 23.32 & 0.98 & 0.59 \\
\hline Metionine & $86.62_{a}$ & $88.40_{\mathrm{a}}$ & $80.74_{b}$ & 4.81 & 0.54 & 0.47 \\
\hline Met+Cys & $74.22_{\mathrm{a}}$ & $76.06_{a}$ & $62.29 \mathrm{~b}$ & 8.62 & 0.94 & 0.70 \\
\hline Arginine & $91.40_{\mathrm{a}}$ & $91.30_{\mathrm{a}}$ & $85.02_{b}$ & 2.92 & 1.97 & 1.80 \\
\hline Histidine & 68.64 & 69.14 & 62.64 & 9.95 & 0.64 & 0.44 \\
\hline Ilesoleucine & $76.61_{\mathrm{a}}$ & $77.29 \mathrm{a}$ & $68.67_{b}$ & 8.12 & 1.00 & 0.77 \\
\hline Leucine & $78.47_{\mathrm{a}}$ & 77.95 & $69.19_{\mathrm{b}}$ & 7.80 & 1.64 & 1.29 \\
\hline Valine & 70.07 & 69.94 & 61.67 & 11.01 & 1.20 & 0.84 \\
\hline \multicolumn{7}{|c|}{ Non-essential amino acids } \\
\hline Serine & $66.31_{a}$ & $70.48_{a}$ & $57.34_{b}$ & 9.65 & 1.14 & 0.76 \\
\hline Ac Asp & $71.07_{\mathrm{ab}}$ & $75.54_{a}$ & $68.27_{b}$ & 6.20 & 4.92 & 3.50 \\
\hline Ac Glu & $84.11_{\mathrm{ab}}$ & $87.50^{\mathrm{a}}{ }_{\mathrm{a}}$ & $81.25_{\mathrm{b}}$ & 4.41 & 4.92 & 4.14 \\
\hline Cystine & $61.63_{\mathrm{a}}$ & $63.48_{\mathrm{a}}$ & $41.46_{b}$ & 24.53 & 0.40 & 0.25 \\
\hline Alanine & 70.36 & 69.46 & 63.02 & 8.44 & 1.15 & 0.81 \\
\hline
\end{tabular}

${ }^{1}$ Coefficient of variation (\%); ${ }^{2}$ total amino acids (\%); ${ }^{3}$ digestible amino acids (\%).

Source: Elaboration of the authors.

According Borges et al. (2005), who compared the delivery of 25 and $50 \mathrm{~g}$ of other fibrous foods, the lowest level of supply CDV has lower values due to interference from the endogenous portion coupled to the low digestibility of these foods, because the content and fibre type promote endogenous secretions, which may contribute to increased endogenous excretion in birds fed high fibre, leading to an underestimation of the amino acid digestibility.

Sunflower cake made up composed similarly to soybean meal amino acids having desirable levels of sulphur and amino acids methionine and cystine, but being deficient in lysine (ANTOSZKIEWICZ; TYWONCZUC; MATUSEVICIUS, 2004).

Values were calculated based on digestible amino acid true digestibility coefficients found that the treatment used $30 \mathrm{~g}$ of food with a 12-hour interval between the first and second delivery. The content of lysine found $(0.85 \%)$ is similar to values reported by Tavernari et al. (2010) who evaluated sunflower meal, but some authors have reported higher values, such as Stringhini et al. (2000) and Sauvant, Perez and Tran (2004) who reported values of $0.95 \%$ and $1.00 \%$, respectively.

The digestibility determines the amount of amino acids that is actually utilized by the animals (NUNES et al., 2001). The digestibility of protein and amino acids in the by-products depends on the temperature and processing systems, as well as the proportions of raw materials used (BRUMANO et al., 2006).

Arginine and methionine are essential amino acids and have the highest rates of true digestibility $(91.40 \%)$. The lowest values were for threonine, histidine and lysine.

Seerley et al. (1974) tested different temperatures of extracting oil from sunflower seed and reported that the lysine content was greater at $100^{\circ} \mathrm{C}$ than that found at $127^{\circ} \mathrm{C}$. At high temperatures, the epsilon group of lysine binds to a carbohydrate and this 
makes it less available amino acids (HERKELMAN; CROMWELL, 1990), suggesting that the limitation of lysine for the cake could be smaller due to the fact that the mechanical process does not use high temperatures as in solvent extraction.

Due to the low content of lysine and high fibre, high inclusion of these co-products of the sunflower in feeds for birds is limited. This high fibre content present in food energy value and decreases the use of nutrients for chickens.

Chlorogenic acid (CGA) is an anti-nutritional factor present in sunflower seed that may have influenced the results (LIMA et al., 2013). The sunflower seed has varying amounts of this acid in the composition (PEDROSA et al., 2000), and second Farag (1999) this variation is due to cultivar, showing an average seed the full content of $2 \%$. Chlorogenic acid inhibits enzymes such as trypsin and lipase, and can hinder the use of nutrients and energy (MUSZYNSKA; REIFER, 1970). The presence ofCGA in sunflower cake is associated with the development and dark green or brown aqueous workup under basic conditions. The browning reaction occurs by the action of polyphenol oxidase that oxidizes the CGA and the resulting substances react with the protein, reducing the amount of essential amino acids, digestibility and nutritional quality, in addition to changing the functionality and acceptability of proteins (PEDROSA et al., 2000; MARTINEZ; DUVNJAK, 2006), so may have interfered in the coefficient of true digestibility of amino acids of sunflower cake.

Trevino, Rebole and Rodriguez (1998) evaluated concentrations of up to 6 g. $\mathrm{kg}^{-1}$ of chlorogenic acid in diets, which is equal to the use of up to $300 \mathrm{~g} . \mathrm{kg}^{-}$ 1 , i.e. $30 \%$ inclusion in the diet for broiler chicks, and found that this did not affect the amount of metabolizable energy and amino acid digestibility.

\section{Conclusions}

The obtained energy and nutritional values indicate that sunflower cake may be included in the feed of broilers. However, attention should be paid to the high fibre content or other antinutritional factors that may be present in this food. To minimize the impact of these aspects, ongoing assessments should be made in order to obtain consistent results that can be used with greater precision when co-products are included in the diet of broiler chickens, further studies should be performed to try to increase the efficiency of use this co-product in diets for broilers.

\section{Acknowledgements}

We thank the Araucaria Foundation for funding, thus enabling the development of the project.

All procedures performed on animals were approved by the Ethics Committee for animal experimentation and practical classes (CEEAAP/ Unioeste) (CEEAAP/Unioeste) da Universidade Estadual do Oeste do Paraná, under protocol number 04411.

\section{References}

AGUIAR, R. H. A.; FANTINATTI, J. B.; GROTH, D.; USBERTI, R. Qualidade física, fisiológica e sanitária de sementes de girassol de diferentes tamanhos. Revista Brasileira de Sementes, Brasília, v. 23, p. 134-139, 2001.

ANTOSZKIEWICZ, Z.; TYWONCZUC, J.; MATUSEVICIUS, P. Effect in indusion of sunflower cake and enzymatic preparations diets for grouwing pigs. Veterinarija ir Zootechnika, Kaunas, v. 26, n. 48, p. 1722, 2004.

BORGES, F. M. O.; ROSTAGNO, H. S.; SAAD, C. E. P.; LARA, L. B.; TEIXEIRA, E. A. Efeito do nível de ingestão sobre a digestibilidade dos aminoácidos em frangos de corte. Ciência Agrotécnica, Lavras, v. 29, n. 2, p. 444-452, 2005.

BRUMANO, G.; GOMES, P. C.; ROSTAGNO, H. S.; ALBINO, L. F. T.; SCHMIDT, M.; GENEROSO, R. A. R. Aminoácidos digestíveis verdadeiros de alimentos protéicos determinados em galos cecectomizados. Revista Brasileira de Zootecnia, Viçosa, v. 35, n. 6, p. 2290-2296, 2006. 
CHUNG, S.; OLIVEIRA, C. R. C.; SOUZA, J. G.; AGUIAR, E. M.; BRASIL, D. F. Avaliação físicoquímica da torta de girassol (Helianthus annuus L.) para a utilização na alimentação animal. In: CONGRESSO INTERNACIONAL DE ZOOTECNIA, 11, 2009, Águas de Lindóia. Anais... Águas de Lindóia: Zootec, 2009, p. 3.

COMPANHIA NACIONAL DE ABASTECIMENTO CONAB.Acompanhamento da safra brasileira 2011/2012. 2012. Disponível em: <http://www.conab.gov.br/ OlalaCMS/uploads/arquivos/girassoloutubro2012>. Acesso em: 15 mar 2013.

COSTA, M. C. R.; SILVA, C. A.; PINHEIRO, J. W. Utilização da torta de girassol na alimentação de suínos nas fases de crescimento e terminação: Efeitos no desempenho e nas características de carcaça. Revista Brasileira de Zootecnia, Viçosa, v. 34, n. 5, p. 15811588, 2005.

FARAG, M. D. E. D. H. Effect of radiation and other processing methods on protein quality of sunflower meal. Journal of the Science of Food and Agriculture, London, v. 79, n. 12, p. 1565-1570, 1999.

FONSECA, N. A. N.; PINHEIRO, J. W.; BRUNELLI, S. R.; SILVA, C. A.; SAZAKA, J. H. Torta de girassol na alimentação de frangos de corte. In: CONGRESSO INTERNACIONAL DE ZOOTECNIA, 9., 2007, Londrina. Anais... Londrina: ZOOTEC, 2007. p. 6.

FREITAS, E. R.; SAKOMURA, N. K.; EZEQUIEL, J. M. B.; NEME, R.; MENDONÇA, M. O. Energia metabolizável de alimentos na formulação de ração para frangos de corte. Pesquisa Agropecuária Brasileira, Brasília, v. 41, n. 1, p. 107-115, 2006.

GENEROSO, R. A. R.; GOMES, P. C.; ROSTAGNO, H. S.; ALBINO, L. F. T.; BARRETO, S. L. T.; BRUMANO, G. Composição química e energética de alguns alimentos para frangos de corte em duas idades. Revista Brasileira de Zootecnia, Viçosa, v. 37, n. 7, p. 1251-1256, 2008.

HERKELMAN, K. L.; CROMWELL, A. G. Utilization of full fat soybean by swine reviewed. Feedstuffs, Bloomington, v. 62, n. 17, p. 13-22, 1990.

KARUNAJEEWA, H.; THAN, S. H.; ABU-SEREWA, S. Sunflower seed meal, sunflower oil and full-fat sunflower seeds, hulls and kernels for laying hens. Animal Feed Science Technology, Amsterdam, v. 26, n.1, p. 45-54, 1989.

LIMA, H. F. F.; FERNANDES, R. T. V.; COSTA, K. M. O.; SILVA, S. L. G.; MARINHO, J. B. M.; VASCONSELOS, N. V. B.; ARRUDA, A. M. V. Farelo de girassol na alimentação de aves label rouge em crescimento no ambiente equatorial. Acta Veterinaria Brasilica, Mossoró, v. 7, n. 1, p. 56-60, 2013.
MARTINEZ, E.; DUVNJAK, Z. Enzymatic degradation of chlorogenic acid using a polyphenol oxidase preparation from the white-rot fungus Trametes versicolor ATCC 42530. Process Biochemistry, London, v. 41, n. 8, p. 1835-1841, 2006.

MATTERSON, L. D.; POTTER, L. M.; STUTZ, M. W. The metabolizable energy of feed ingredients for chickens. Agricultural Experiment Station Research Report, University of Connecticut, v. 11, n. 7, p. 3-11, 1965.

MONTAGNE, L.; PLUSKE, J. R.; HAMPSON, D. J. A review of interactions between dietary fibre and intestinal mucosa, and their consequences on digestive health in young no-ruminant animals. Animal Feed Science and Technology, Amsterdam, v. 108, n. 4, p. 95-117, 2003.

MUSZYNSKA, G.; REIFER, I. The arginase inhibitor from sunflower seeds: purification and inhibitory properties. Acta Biochemica Polonica, Warszawa, v. 17, n. 4, p. 247-252, 1970.

NUNES, R. V.; ROSTAGNO, H. S.; ALBINO, L. F. T.; GOMES, P. C.; NASCIMENTO, A. H. Valores de aminoácidos digestíveis verdadeiros e equações de predição dos aminoácidos digestíveis do grão e de subprodutos do trigo para aves. Revista Brasileira de Zootecnia, Viçosa, v. 30, n. 3, p. 774-784, 2001.

OLIVEIRA, D. D.; PINHEIRO, J. W.; FONSECA, N. A. N.; OBA, A. Desempenho de frangos de corte alimentados com torta de girassol. Semina: Ciências Agrárias, Londrina, v. 33, n. 5, p. 1979-1990, set./out. 2012.

OLIVEIRA, M. D. S.; MOTA, D. A.; BARBOSA, J. C.; STEIN, M.; BORGONOVI, F. Composição bromatológica e digestibilidade ruminal in vitro de concentrados contendo diferentes níveis de torta de girassol. Ciência Animal Brasileira, Goiânia, v. 8, n. 4, p. 629-638, 2007.

OLIVEIRA, M. F.; VIEIRA, O. V. Extração de óleo de girassol utilizando miniprensa. Londrina: EMBRAPACNPSo, EMBRAPA-CNPSo. 2004. 27 p. (Documentos, 237).

PEDREIRO, G. E. G.; SILVA, C. A.; BRIDI, A. M.; FONSECA, N. A. N.; PINHEIRO, J. W.; SANTOS, J. M. G. Torta de girassol na alimentação de matrizes suínas em gestação e lactação. Semina: Ciências Agrárias, Londrina, v. 30, n. 2, p. 497-504, 2009.

PEDROSA, M. M.; MUSQUIZ, M.; GARCIAVALLEJO, C.; BURBANO, C.; CUADRADO, C.; AYET, G.; ROBREDO, L. M. Determination of caffeic and chlorogenic acids and their derivatives in different sunflower seeds. Journal of the Science of Food and Agriculture, London, v. 80, n. 4, p. 459-464, 2000. 
PELIZZERI, R. N.; POZZA, P. C.; OLIVEIRA, N. T. E.; SOMENSI, M. L.; FURLAN, A. C.; NEUMANN, M.E. Avaliação de modelos de predição da energia metabolizável do milho para suínos. Arquivo Brasileiro de Medicina Veterinária e Zootecnia, Belo Horizonte, v. 65, n. 2, p. 460-468, 2013.

PEREIRA, E. S.; PIMENTEL, P. G.; BOMFIM, M. A. D.; CÂNDIDO, M. J. D. Torta de girassol em rações de vacas em lactação: produção microbiana, produção, composição e perfil de ácidos graxos do leite. Acta Scientarum Animal Sciences, Maringá, v. 33, n. 4, p. $387-$ 394, 2011.

PINHEIRO, J. W.; BRUNELLI, S. R.; FONSECA, N. A.; OBA, A.; SILVA, C. A.; SILVA, V. A.; CASTRO, L. M.; FERNANDES, P. A.; PASSAMAI, A. P. S.; PIATTO, V. C. Avaliação do valor nutritivo e energético da torta de girassol para frangos de corte. In: CONGRESSO INTERNACIONAL DE ZOOTECNIA, 9., 2007, Londrina. Anais... Londrina: ZOOTEC, 2007. p. 1-5.

RAMOS, L. S. N.; LOPES, J.B.; FIGUEIRÊDO, A.V.; FREITAS, A. C.; FARIAS, L. A.; SANTOS, L. S. Metabolizabilidade dos nutrientes em frangos de corte alimentados com rações contendo diferentes níveis da polpa de caju desidratada. Revista Cientifica Produção Animal, v. 9, n. 2, p. 137-145, 2007.

ROSTAGNO, H. S.; ALBINO, L. F. T.; DONZELE, J. L.; GOMES, P. C.; OLIVEIRA, R. F.; LOPES, D. C.; FERREIRAS, A. S.; BARRETO, S. L. T.; EUCLIDES, R. F. Tabelas brasileiras para aves e suínos: composição de alimentos e exigências nutricionais. 3. ed. Viçosa: UFV, Departamento de Zootecnia, 2011. p. 186.

ROSTAGNO, H. S.; FEATHERSTON, W. R. Estudos de métodos para determinar disponibilidade de aminoácidos em pintos. Revista da Sociedade Brasileira de Zootecnia, Viçosa, v. 6, n. 1, p. 64-76, 1977.

SAKOMURA, N. K.; ROSTAGNO, H. S. Métodos de pesquisa em nutrição de monogástricos. Jaboticabal: Funep, 2007, 283 p.

SANTOS, A. X.; OLIVEIRA, A. A.; MASSARO JUNIOR, F. L.; LANÇANOVA, A. C.; SILVA, L. D. F.; PECORARO, C.; LEME, M. C. J. Torta de girassol na dieta de vacas em lactação. In: REUNIÃO ANUAL DA SOCIEDADE BRASILEIRA DE ZOOTECNIA, 46., 2009, Maringá. Anais... Maringá: SBZ, 2009.
SAUVANT, D.; PEREZ, J. M.; TRAN, G. Tablas de composición y de valor nutritivo de lasmaterias primas destinadas a losanimales de interés ganadero: cerdos, aves, bovinos, ovinos, caprinos, conejos, caballos, peces. Madrid: Mundi-Prensa, 2004. 195 p.

SEERLEY, R. W.; BURDICK, D.; RUSSOM, W. C.; LOWREY, R. S.; MACCAMPBELL, H. C.; AMOS, H. E. Sunflower meal as a replacement for soybean meal in growing swine and rats diets. Journal of Animal Science, Champaign, v. 38, n. 5, p. 947-953, 1974.

SIBBALD, I. R. A bioassay for available amino acids and true metabolizable energy in feedstuffs. Poultry Science, Savoy, v. 55, n. 3, p. 303-308, 1976.

SILVA, C. A.; PINHEIRO, J. W.; FONSECA, N. A. N.; CABRERA, L.; HOSHI, E. H.; SARUBBI, J.; COSTA, M. C. R.; PACHECO, G. D.; TELLES, H.; HIDESHIMA, C. S.; SOUZA, N. E. Grão de girassol na alimentação de suínos em crescimento e terminação: digestibilidade, desempenho e efeitos na qualidade de carcaça. Semina: Ciências Agrárias, Londrina, v. 24, n. 1, p. 93-102, 2003.

SILVA, C. A.; AGOSTINI, P. S. Utilização da torta de girassol em suínos. Pubvet, Londrina, v. 1, n. 11, ed. 11, p. 1982-1263, 2007.

SILVA, D. J.; QUEIROZ, A. C. Análise de alimentos: métodos químicos e biológicos. Viçosa: UFV, Imp. Univ., 2002. 235 p.

STRINGHINI, J. H.; CAFÉ, M. B.; FERNANDES, C. M.; ANDRADE, M. L.; ROCHA, P. T.; LEANDRO, N. S. M. Avaliação do valor nutritivo do farelo de girassol para aves. Ciência Animal Brasileira, Goiânia, v. 1, n. 2, p. 123-126, 2000.

TAVERNARI, F. C.; MORATA, R. L.; RIBEIRO JÚNIOR, V.; ALBINO, L. F. T.; DUTRA JÚNIOR, W. M.; ROSTAGNO, H. S. Avaliação nutricional e energética do farelo de girassol para aves. Arquivo Brasileiro de Medicina Veterinária e Zootecnia, Belo Horizonte, v. 62, n. 1, p. 172-177, 2010.

VIEIRA, S. L.; PENZ JUNIOR, A. M.; LEBOUTE, E. M.; CORTELINE, J. A nutritional evaluation of a high fiber sunflower meal. Journal Applied Poultry Research, Champaign, v. 1, n. 4, p. 382-388, 1992.

WENK, C. The role of fibre in digestive physiology of the pig. Animal Feed Science and Technology, Amsterdam, v. 90 , n. 2, p. 21-33, 2001. 